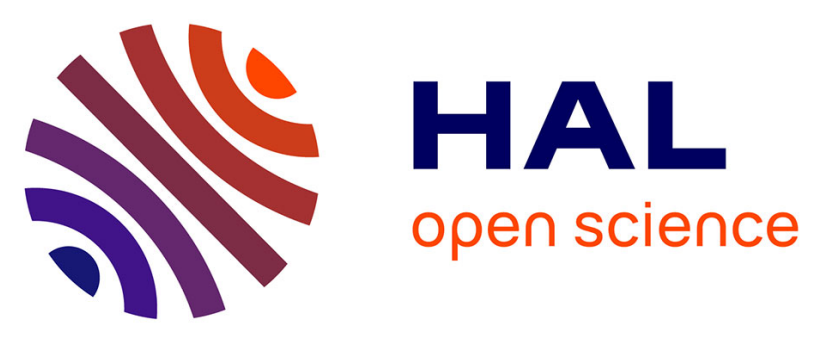

\title{
Microorganism dynamics in a mudflat during rising tide Microorganism dynamics during a rising tide: Disentangling effects of resuspension and mixing with offshore waters above an intertidal mudflat
} Katell Guizien, Christine Dupuy, Pascaline Ory, Hélène Montanié, Hans Hartmann, Mathieu Chatelain, Mikhaïl Karpytchev

\section{To cite this version:}

Katell Guizien, Christine Dupuy, Pascaline Ory, Hélène Montanié, Hans Hartmann, et al.. Microorganism dynamics in a mudflat during rising tide Microorganism dynamics during a rising tide: Disentangling effects of resuspension and mixing with offshore waters above an intertidal mudflat. Journal of Marine Systems, 2013, 10.1016/j.jmarsys.2013.05.010 . hal-01248055

\section{HAL Id: hal-01248055 https://hal.science/hal-01248055}

Submitted on 26 Dec 2016

HAL is a multi-disciplinary open access archive for the deposit and dissemination of scientific research documents, whether they are published or not. The documents may come from teaching and research institutions in France or abroad, or from public or private research centers.
L'archive ouverte pluridisciplinaire HAL, est destinée au dépôt et à la diffusion de documents scientifiques de niveau recherche, publiés ou non, émanant des établissements d'enseignement et de recherche français ou étrangers, des laboratoires publics ou privés. 
1 Running title: Microorganism dynamics in a mudflat during rising tide

4 Microorganism dynamics during a rising tide: Disentangling effects of resuspension and

5 mixing with offshore waters above an intertidal mudflat

6

7 Katell Guizien ${ }^{1+*}$, Christine Dupuy ${ }^{2 \dagger}$, Pascaline Ory $^{2}$, Hélène Montanié ${ }^{2}$, Hans

8 Hartmann$^{2}$, Mathieu Chatelain ${ }^{1, * *}$, Mikhail Karpytchev ${ }^{2}$

1. Laboratoire d'Ecogéochimie des Environnements Benthiques, Observatoire Océanologique de Banyuls-sur-Mer, UMR8222, CNRS-Université Pierre et Marie Curie, rue du Fontaulé, 66650 Banyuls-sur-Mer, France

2. Littoral, Environnement et SociétéS (LIENSs), Université de La Rochelle, UMR 7266 CNRS-ULR, 2 rue Olympe de Gouges, 17000 La Rochelle Cedex, France

*Corresponding author: guizien@obs-banyuls.fr, Tel: +33 (0) 468887 319, Fax: +33 (0)

** Present address: Deltares, P.O. Box 177, 2600 MH Delft, The Netherlands

22 Keywords: microorganisms dynamics, bentho-pelagic coupling, resuspension, tidal mudflat 


\section{Abstract}

29 Resuspension of microphytobenthic biomass that builds up during low tide has been

30 acknowledged as a major driver of the highly productive food web of intertidal mudflats. Yet,

31 little is known about the contribution to pelagic food web of the resuspension of other

32 microorganisms such as viruses, picoeukaryotes, cyanobacteria, bacteria, nanoflagellates, and

33 ciliates, living in biofilms associated with microphytobenthos and surficial sediment. In the

34 present study, a novel approach that involves simultaneous Lagrangian and Eulerian surveys

35 enabled to disentangle the effects of resuspension and mixing with offshore waters on the

36 dynamics of water column microorganisms during a rising tide in the presence of waves.

37 Temporal changes in the concentration of microorganisms present in the water column were

38 recorded along a $3 \mathrm{~km}$ cross-shore transect and at a fixed subtidal location. In both surveys,

39 physical and biological processes were separated by comparing the time-evolution of

40 sedimentary particles and microorganisms concentrations. During a rising tide, sediment

41 erosion under waves action occurred over the lower and upper part of the mudflat, where

42 erodibility was highest. Although erosion was expected to enrich the water column with the

43 most abundant benthic microorganisms, such as diatoms, bacteria and viruses, enrichment

44 was only observed for nanoflagellates and ciliates. Grazing probably overwhelmed erosion

45 transfer for diatoms and bacteria, while adsorption on clayed particles may have masked the

46 expected water column enrichment in free viruses due to resuspension. Ciliate enrichment

47 could not be attributed to resuspension as those organisms were absent from the sediment.

48 Wave agitation during the water flow on the mudflat likely dispersed gregarious ciliates over

49 the entire water column. During the rising tide, offshore waters imported more autotrophic,

50 mainly cyanobacteria genus Synechococcus sp. than heterotrophic microorganisms, but this

51 import was also heavily grazed. Finally, the water column became a less heterotrophic

52 structure in the subtidal part of the semi-enclosed bay, where mixing with offshore waters

53 occurs (50\% decrease), compared to the intertidal mudflat, when resuspension occurs. The 
54 present study suggests that this differential evolution resulted predominantly from dilution

55 with offshore waters less rich in heterotrophic microorganisms. Indeed, any input of

56 microorganisms accompanying physical transfers due to bed erosion or offshore waters

57 mixing was immediately buffered, probably to the benefit of grazers.

\section{1. Introduction}

60 The productivity of coastal systems, especially intertidal mudflats, and their capacity

61 to enrich adjacent terrestrial and marine zones through trophic pathways (i.e. export by mobile

62 consumers) and hydrodynamic pathways (i.e. waves, wave-generated currents, estuarine

63 currents and tides) is now common knowledge. The biological productivity of intertidal

64 mudflats is due to the intense activity of benthic microorganism communities. During 65 emersion, epipelic diatoms (microphytobenthos, MPB) form a biofilm (up to $20 \mathrm{mg}$ 66 chlorophyll $a \mathrm{~m}^{2}$ ) in the top centimeter layer of a mud surface (Blanchard and Cariou-Le Gall 67 1994; Blanchard et al. 1997; Herlory et al. 2004). Prokaryote communities are associated with 68 this biofilm, and bacterial production (secondary production) can be as high or even higher 69 than MPB production (primary production) (Cammen 1991; Garet 1996; Van Duyl and Kop 70 1994). Bacterial concentration is generally about $10^{9}$ cells per $\mathrm{cm}^{3}$ in a mudflat (Schmidt et al. 71 1998). Nanoflagellate concentrations range from 100 to several million cells per mL of 72 sediment (Gasol 1993), with greater concentrations in surficial sediment (Alongi 1991). 73 Conversely, ciliates are more abundant in fine sand (Fenchel 1969; Kemp 1988; Epstein 74 1997) compared to muddy sediment enriched with organic matter (Giere 1993). Viruses are 75 also abundant in marine sediments (Danovaro et al. 2008).

76 Resuspension of microorganisms living either in the pore water of surficial sediment 77 or attached to surficial sedimentary particles have been reported under tidal currents at 78 subtidal sites (Shimeta et al. 2002). Large tidal currents in macrotidal bays are likely to induce 79 unconsolidated sediment resuspension (Mehta et al. 1989). Yet, resuspension of sediment 
across intertidal mudflats, where recurrent desiccation promoted sediment consolidation

81 (Anderson and Howel 1984), generally requires higher shear stress than those induced by tidal

82 current and has been mainly attributed to wave action (Bassoulet et al. 2000; French et al.

83 2008). However, sediment erodibility thresholds may be significantly reduced (bed friction

84 velocity below $3 \mathrm{~cm} \mathrm{~s}^{-1}$ ) due to macrofaunal bioturbation activity (Orvain et al. 2007). Resuspended microorganisms may greatly affect pelagic and benthic food webs.

86 Resuspended diatoms and autotrophic nanoflagellates may alter phytoplankton community

87 structure, enhance phytoplankton biomass and modify the size structure of primary producers,

88 ultimately modifying microbial food web function (Marquis et al. 2007; Ory et al. 2010). In

89 addition, resuspended heterotrophic cells, such as nanoflagellates, prokaryotes (bacteria and

90 archaea) and viruses, can affect the function of the food web, and favour the microbial loop or

91 the viral shunt (Wainright 1987; Garstecki et al. 2002; Seymour et al. 2007). Furthermore,

92 some of these resuspended microorganisms may be used as food resources for 93 mesozooplankton and benthic suspension feeders (Carslon et al. 1984), such as oysters

94 (Dupuy et al. 2000) and bivalve mollusks (Scrobicularia plana) (Hughes 1969).

Many studies have investigated the dynamics of the MPB biomass, including

96 resuspension of these microorganisms (Lucas et al. 2000; Shimeta et al. 2002; Guarini et al.

97 2008). Some studies have qualitatively and quantitatively evaluated the resuspension of other

98 microorganisms present in the intertidal mudflat. Protist and bacteria resuspension thresholds

99 have been quantified at a subtidal coastal site with in situ flumes and sampling of the benthic

100 boundary layer during tidal accelerations (Shimeta and Sisson 1999; Shimeta et al. 2002).

101 Shimeta et al. (2003) studied the resuspension of benthic protists at subtidal coastal sites with

102 differing sediment compositions. Other studies have explored the effects of sediment

103 resuspension on a coastal planktonic microbial food web, either experimentally (Garstecki et

104 al. 2002; Pusceddu et al. 2005; Wu et al. 2007) or in the field (Grémare et al. 2003). However,

105 in field studies, resuspension is often accompanied by other physical processes, such as river 
106 flooding and tidal rise, which require adapted sampling strategies to separate the contribution 107 of each process.

108 In the current study, we applied a novel approach based on two simultaneous 109 Lagrangian and Eulerian field surveys to disentangle the effect of resuspension and mixing 110 with offshore waters on the dynamics of water column microorganisms during a tidal flow.

111 The time-evolution of microorganisms, including viruses, autotrophic protists, heterotrophic 112 protists and prokaryotes present in the water column, were carried out at one fixed location 113 (Eulerian) and one mobile station (Lagrangian) in the Marennes-Oleron bay (French Atlantic 114 coast). In both surveys, physical and biological processes were separated by comparing the 115 time-evolution of suspended sediment particles and microorganisms concentrations.

\section{Methods}

\subsection{Study site and sampling strategy}

The study was carried out during the afternoon rising tide (tidal amplitude of $3.8 \mathrm{~m}$ ) in

120 the Bay of Marennes-Oléron (BMO) on 24 July, 2008. Located between the mainland French

121 Atlantic coast and Oléron Island, BMO is a macrotidal bay with a tidal range up to $6 \mathrm{~m}$ during 122 spring tides. This macrotidal system is influenced by continental inputs, mainly from the

123 Charente River to the north of the BMO (monthly average discharge was $30 \mathrm{~m}^{3} \mathrm{~s}^{-1}$ in July 124 2008, slightly less than the median value of $40 \mathrm{~m}^{3} \mathrm{~s}^{-1}$ over the last ten years). The BMO 125 covers $170 \mathrm{~km}^{2}$, of which $60 \mathrm{~km}^{2}$ are intertidal mudflats. The Brouage mudflat is $>4 \mathrm{~km}$ wide, 126 and its sediment consists of silt and clay particles $\left(95 \%\right.$ of $<63 \mu \mathrm{m}$, median grain size $\mathrm{d}_{50}=10$ $127 \mu \mathrm{m})$. Triplicate samples of the first $1 \mathrm{~cm}$ layer of sediment were taken at the end of low tide in 128 the upper region of the mudflat (Fig. 1). Only concentrations of bacteria and viruses were 129 assessed in surficial sediment. Two simultaneous field surveys (Lagrangian and Eulerian) 130 were carried out to separate the effect on the dynamics of water column microorganisms of 131 resuspension and mixing with offshore waters during tidal flow. Adopting a Lagrangian 
132 strategy avoided transport flux gradients that occur in an Eulerian survey. Such transport flux

133 gradients occur as the water level changes in an Eulerian survey and pelagic concentrations

134 are generally expected to be mixed (diluted or enriched) by offshore waters in proportion to

135 water depth. Conversely, no mixing (especially dilution) is expected in a Lagrangian survey,

136 where the water level remains constant. In both types of surveys, temporal changes in concentrations of a group of organisms, or particulate or dissolved matter that depart from these expectations indicate an imbalance between the many biogeochemical processes that potentially affect this group (Fig. 2). For particulate matter or living low-motility cells, an overall increase in concentration indicates that either benthic resuspension or population growth dominate, whereas a decrease indicates that either sedimentation mediated by sorption on matters or population decay (e.g. grazing) dominates.

144 using a backward procedure the trajectory of a drifter reaching the shore in the northern part of the Brouage mudflat (Fig. 1) at the end of the rising tide (Nicolle and Karpytchev 2007). The model used a high resolution, finite element grid and TELEMAC software to solve the depth integrated equations of Saint Venant (Hervouet and Van Haren 1994; Hervouet 2007).

148 The Eulerian subtidal station was located at the origin of the drifter trajectory for the case of a no-wind tidal circulation in the BMO (Fig. 1).

151 during the first 2 h 45 min of the rising tide over the intertidal Brouage mudflat, between 152 15:45 $\mathrm{h}$ and 18:30 $\mathrm{h}$ local time (Fig. 1). The tidal front travelled roughly at a speed of $30 \mathrm{~cm} \mathrm{~s}^{-}$ 153 1. Cylindrical drifters (46 cm in diameter and $50 \mathrm{~cm}$ in height) were used to track the 154 advancing tidal currents into the BMO. Drifter walls were made of plastic film wrapped 155 around a thin metal rod armature and a $10 \mathrm{~cm}$ plastic spherical buoy was fixed on its top. The 156 drifter was completely immersed to be directed by surface currents and the buoyant sphere 157 which emerged from water was used to keep track of the drifter position. The drifter was 
158 tracked using a flatboat which engine was stopped and left drifting for at least 5 min before

159 sampling in order to avoid bottom resuspension artefacts. Water samples were obtained at five 160 different stations along the $3 \mathrm{~km}$ cross-shore transect (Fig. 1) on 24 July, 2008. Due to rapid 161 drifting when the engine was stopped before sampling, first Lagrangian station was already 162 located a $100 \mathrm{~m}$ away from the Eulerian station. Water depth varied little during the 163 Lagrangian survey, ranging from 40 to $70 \mathrm{~cm}$. One sample was collected in the middle of the 164 water column at each station using a $1 \mathrm{~L}$ plastic bottle attached to a graduated stick. Short wave agitation combined with limited water depth during the Lagrangian survey did not allow sampling with an open-ended Nisking bottle, so a smaller closed-bottom bottle was used. However, sampling bias due to accumulation of settling particles in a closed-bottom bottle was reduced by a fast sampling lasting less than a few seconds and by introducing the bottle upside down. Since wave length was greater than water depth, short wave agitation ensured sufficient mixing over the entire water depth, making it safe to assume no stratification for all sampled microorganisms (except very close to the bottom) occurred during the Lagrangian survey. Each individual sample was divided into multiple aliquots to perform replicate counts. Immediately before preparation of aliquots, each sample was gently agitated and subsampling was performed very quickly to prevent sedimentation.

The Eulerian survey consisted of sampling the water column with horizontal 3 L Niskin bottles at the same subtidal spot during the rising tide, starting at low tide (Fig. 1). Water depth at the sampling station increased from $1.10 \mathrm{~m}$ at the beginning of the survey to $3.1 \mathrm{~m}$ at the end of sampling. Three water samples were taken $0.5 \mathrm{~m}$ below the surface and $0.5 \mathrm{~m}$ above the bottom of the water column during the first 2 h 45 min of the rising tide on 24 July, 2008. Aliquots of each sample were prepared as described above.

Mean and standard deviation of all variables at the beginning of the rising tide were computed from the three samples taken at time zero of the Eulerian and Lagrangian surveys. 
184 An 80\% confidence interval for this initial measurement was computed using a Student law $185\left(\mathrm{t}_{\mathrm{n}-1}(1-\alpha)=1.886, \alpha=10 \%\right)$. Evolution of the concentration of particulate inorganic matter 186 (PIM) and each microorganism at the Eulerian site were predicted using on a simple mixing 187 model based on water depth evolution, assuming that the (1) water column was well-mixed at 188 the Eulerian site and (2) concentration of PIM or each microorganismin incoming waters 189 could be estimated from the average concentration measured to the north of the BMO basin 190 taken before the experiment then 15 days after. The average concentration PIM or each 191 microorganism expected after mixing with offshore waters during tidal flow, $\mathrm{C}_{t}$, was 192 calculated during the Eulerian survey for sampling times after $1 \mathrm{~h} 15 \mathrm{~min}$ and $2 \mathrm{~h} 45 \mathrm{~min}$ as follows:

$$
C_{t}=C_{0} \frac{h_{0}}{h_{t}}+C_{e x t}\left[1-\frac{h_{0}}{h_{t}}\right]
$$

195 where $C_{0}$ is the average concentration at time zero of the Eulerian survey, $h_{0}$ is the water depth 196 at this time, $h_{t}$ is the water depth at time $t$ and $C_{\text {ext }}$ is the average offshore concentration. An $19780 \%$ confidence interval for this predicted value was build applying a Student law $(n=3)$ using 198 standard deviation of $\mathrm{C}_{0}$ and $\mathrm{C}_{\mathrm{ext}}$. Backward trajectories reaching the Eulerian survey 199 sampling station after $1 \mathrm{~h} 15 \mathrm{~min}$ and $2 \mathrm{~h} 45 \mathrm{~min}$ were also computed for the the case of no-wind 200 tidal circulation in the BMO with the 2D barotropic model and indicated that offshore waters most probably came from the northern entrance of the BMO, west of the Charente river mouth (Fig. 1). In the absence of river flooding over the summer period, the impact of the Charente river on the pelagic ecosystem was limited at this location (Stanisière, personal communication), allowing us to assume that the concentration in the north of the BMO was spatially uniform (Ory et al. 2010). Offshore concentrations at $0.5 \mathrm{~m}$ below the surface were measured on July 12 and 29, 2008, at a subtidal station roughly $15 \mathrm{~km}$ northwest of the BMO (water depth $=17 \mathrm{~m}, 46.1153^{\circ} \mathrm{N}, 01.4139^{\circ} \mathrm{Wr}$ ). Values for $\mathrm{C}_{\text {ext }}$ on July 24 were interpolated 
uncertainty on offshore concentrations on the day of the survey was accounted for using

210 standard deviation between the two dates. Variability estimate based on those two days are

211 similar to within day variability (H. Montanié, personal communication) and to within

212 summer variability (Ory et al., 2010) in the north of BMO basin.

\subsection{Physical forcings}

Hydrological parameters, such as temperature and salinity, were recorded on board

216 with multi-parameter probes (YSI 6600EDS-M) during the Eulerian survey. Average wind

217 speed and direction were measured every hour by Météo-France at the La Rochelle

218 Aérodrome meteorological station $\left(46.1733^{\circ} \mathrm{N}, 1.1883^{\circ} \mathrm{W}\right.$, roughly $20 \mathrm{~km}$ north of the BMO).

219 A single-point Nortek acoustic Doppler velocimeter (ADV) was used to measure the 3D

220 velocity at $15.6 \mathrm{~cm}$ a.b. (above bottom, outside the wave boundary layer which thickness

221 yielded $3 \mathrm{~cm}$ at maximum, Fredsoe and Deigaard,1992) and pressure as soon as the tide level

222 was higher than $50 \mathrm{~cm}$ at the location $45.9161^{\circ} \mathrm{N}, 1.0890^{\circ} \mathrm{W}$ (Fig. 1). Thus, ADV data

223 collection was interrupted during low tide from 12:45 h to 18:15 h on 24 July, 2008.

224 Measurements consisted of $2 \mathrm{~min} 30 \mathrm{~s}$ time series recorded at a frequency of $32 \mathrm{~Hz}$ every 15

225 min for the three velocity components and pressure. Turbulent Reynolds shear stress outside

226 the wave boundary layer were computed as the covariance of horizontal and vertical velocity

227 deviations from the mean flow after removing wave-induced velocities. Wave-induced

228 velocities were computed by applying a $0.5 \mathrm{~Hz}$ low pass filtering on raw velocity

229 measurements (Guizien et al. 2010). Assuming a logarithmic boundary layer, bed shear stress

230 associated with tidal current was then linearly extrapolated to the bed using Reynolds shear

231 stress measured at $15.6 \mathrm{~cm}$ a.b. and zero Reynolds shear stress at the free surface.

232 Wave density spectra were computed from pressure time series sampled at $4 \mathrm{~Hz}$ and

233 used to derive the wave parameters (i.e. mean spectral period, $\mathrm{T}_{\mathrm{m}}$, and significant height, $\mathrm{H}_{\mathrm{s}}$ )

234 over the Brouage mudflat. Assuming that the wave field was uniform over the mudflat, wave 
orbital velocities at $40 \mathrm{~cm}$ a.b. were derived from $\mathrm{T}_{\mathrm{m}}$ and $\mathrm{H}_{\mathrm{s}}$, according to the linear wave

236 theory for varying water depths, D, at the Eulerian survey site and for a constant water depth

237 of $40 \mathrm{~cm}$ during the Lagrangian survey. Time-dependent bed shear stress associated with a

238 sine wave with these orbital velocities are described by their maximum value and average

239 value over a wave period (half the maximum value) using Guizien and Temperville (1999)

240 parameterization. Bed roughness was assumed to be $0.5 \mathrm{~cm}$ based on the bioroughness height,

241 which could be visually estimated on the mudflat. By definition, bed friction velocity $\left(\mathrm{u}^{*}\right)$

242 either due to waves or to the tidal current is the square root of the bed shear stress divided by

243 seawater density.

\subsection{Particulate inorganic matter (PIM)}

Total particulate matter was measured as previously described by Aminot and

247 Chaussepied (1983). Filters were combusted at $490^{\circ} \mathrm{C}$ for 2 h to eliminate organic carbon content and then weighed. A water sample (from 300 to $1000 \mathrm{~mL}$ ) was filtered onto a Whatman GF/C (47 mm in diameter) under $<10 \mathrm{~mm} \mathrm{Hg}$ vacuum pressure. After sample filtration, each filter was rinsed twice with MilliQ water to remove salt, dried at $60^{\circ} \mathrm{C}$ for $12 \mathrm{~h}$ then weighed to measure total particulate matter. Filters were combusted at $490^{\circ} \mathrm{C}$ for $2 \mathrm{~h}$ to eliminate organic carbon content and then weighed to determine content of particulate 253 inorganic matter (PIM).

\subsection{Enumeration of microorganisms}

Water samples (up to $50 \mathrm{~mL}$ ) were stained with $1 \%$ alkaline Lugol's solution to

visualise microplanktonic cells, such as diatoms, dinoflagellates and ciliates, ranging from 20 to $200 \mu \mathrm{m}$. Microphytoplanktonic cells were counted using an Utermöhl settling chamber

259 (Hydro-Bios ${ }^{\circledR}$ combined plate chambers) under an inverted microscope. Taxonomic determination was carried out in accordance with systematics literature (Nezan, 1996; Ricard, 
261 1987; Sournia, 1986), and benthic species were differentiated from planktonic species based 262 on knowledge of the habitat.

263 For nanoplanktonic cells (3 to $15 \mu \mathrm{m}$ ), water samples (up to $20 \mathrm{~mL}$ ) were fixed using 264 1\% paraformaldehyde then stained with DAPI (4',6'-diamidino-2-phénylindole). Autotrophic 265 nanoflagellates (ANF) and heterotrophic nanoflagellates (HNF) were counted as previously 266 described byby Dupuy et al. (1999), which was a modified methodology from Haas (1982), 267 Caron (1986), and Sherr et al. (1994).

268 For picoeukaryotes (or picophytoeukaryotes) and Synechococcus (1 to $2 \mu \mathrm{m}$ ), water 269 samples (3 mL) were fixed using $2 \%$ formaldehyde, frozen in liquid $\mathrm{N}_{2}$, and counted using a 270 FACSCan flow cytometer (Bd-Bioscience) as previously described by Marie et al. 2000. For viruses $(20 \mathrm{~nm})$, triplicate water samples $(3 \mathrm{~mL})$ were fixed in filtered $2 \%$

272 formaldehyde and stored for less than a day at $4^{\circ} \mathrm{C}$. Samples were then filtered through 0.02 $273 \mu \mathrm{m}$ Anodiscs (25 mm, Whatman) and counted using epifluorescence microscopy after 274 staining for 30 min with Sybr Green I (Noble and Fuhrman, 1998). Viruses were counted in at 275 least 15 random fields of view under blue excitation (Zeiss Axioskop 1000x). Only free 276 viruses were enumerated.

277 For bacteria (1 to $2 \mu \mathrm{m}$ ), triplicate water samples (3 $\mathrm{mL}$ ) were fixed with filtered $2 \%$ 278 formaldehyde and stored for less than a day at $4^{\circ} \mathrm{C}$. Samples were filtered through $0.02 \mu \mathrm{m}$ 279 Anodiscs (25mm, Whatman). Samples were enumerated using epifluorescence microscopy 280 after staining for 30 min with Sybr Green I (Noble and Fuhrman 1998). Bacteria were counted 281 in at least 15 random fields of view under blue excitation (Zeiss Axioskop 1000x). Free 282 bacteria were counted with a fixed focalisation on the filter surface while attached bacteria on 283 aggregates deposited on the filter were screened by varying focal distance.

284 For each group of autotrophic or heterotrophic organisms, biomass was calculated 285 using conversion factor for cell to carbon content (Table 2) multiplied by abundance. 


\subsection{Physical forcings}

On 24 July, a thermal wind in the morning turned from the southeast (land) to the west (sea), reaching a maximum speed of $8.7 \mathrm{~m} \mathrm{~s}^{-1}$ around low tide at 15:00 h (Fig. 3a). Short period waves, with a mean period ranging from 2 to $4 \mathrm{~s}$, started growing under wind action after 11:00 h during ebb tide. At 12:30 h, when the ADV emerged, significant wave height was already $0.15 \mathrm{~m}$ and had increased up to $0.2 \mathrm{~m}$ at $18: 30 \mathrm{~h}$ when ADV was submerged again at the end of the rising tide (Fig. 3a). Given the slight decrease in wind speed after 15:00 $\mathrm{h}$ and based on personal observation, wave height was at least $0.2 \mathrm{~m}$ during the survey period from 15:45 h to 18:30 h. Therefore, a wave height of $0.2 \mathrm{~m}$ was used to estimate bed friction velocity caused by waves. Maximum and mean bed friction velocity due to waves were at least $4.5 \mathrm{~cm} \mathrm{~s}^{-1}$ and $3.2 \mathrm{~cm} \mathrm{~s}^{-1}$, respectively, during the Lagrangian survey under $0.4 \mathrm{~m}$ water depth. In contrast, maximum and mean bed friction velocities due to waves were less than $2 \mathrm{~cm} \mathrm{~s}^{-1}$ and $1.4 \mathrm{~cm} \mathrm{~s}^{-1}$, respectively, when the Eulerian survey started at low tide. These values continuously decreased to $0.5 \mathrm{~cm} \mathrm{~s}^{-1}$ and $0.35 \mathrm{~cm} \mathrm{~s}^{-1}$, respectively, as the water level rose (Fig. 3b). Bed friction velocity induced by the tidal current reached a maximum value of $1.3 \mathrm{~cm} \mathrm{~s}^{-1}$ when the tidal flow arrived at the ADV location (water depth of $0.5 \mathrm{~m}$ ) and rapidly decreased to less than $0.5 \mathrm{~cm} \mathrm{~s}^{-1}$ during the rest of the rising tide over the intertidal mudflat. and Lagrangian surveys

PIM concentration displayed a large spatial variability at the beginning of the rising tide surveys (Fig. 4), with a value that was twice as high in the subtidal site (300 $\mathrm{mg} \mathrm{L}^{-1}$ ) compared to the first Lagrangian sampling station $\left(140 \mathrm{mg} \mathrm{L}^{-1}\right)$. However, at the end of the

311 Lagrangian survey, the PIM concentration had increased more than five-fold, up to $1180 \mathrm{mg}$ $312 \mathrm{~L}^{-1}$, largely overpassing the $80 \%$ confidence interval around the initial average concentration. 
313 Moreover, PIM concentration steadily increased at an average rate of $0.11 \mathrm{mg} \mathrm{L}^{-1} \mathrm{~s}^{-1}$ as tidal

314 flow progressed over the mudflat (Fig. 4). Meanwhile, the rate of increase in the PIM

315 concentration was not constant throughout the survey, reaching $0.18 \mathrm{mg} \mathrm{L}^{-1} \mathrm{~s}^{-1}$ during the first

316 hour, falling to $0.02 \mathrm{mg} \mathrm{L}^{-1} \mathrm{~s}^{-1}$ during the next $40 \mathrm{~min}$ and again increasing to $0.12 \mathrm{mg} \mathrm{L}^{-1} \mathrm{~s}^{-1}$

317 for $30 \mathrm{~min}$ before falling again to $0.05 \mathrm{mg} \mathrm{L}^{-1} \mathrm{~s}^{-1}$ during the last $30 \mathrm{~min}$. Assuming a uniform

318 vertical PIM concentration over the $0.4 \mathrm{~m}$ water depth due to strong wave agitation, erosion

319 rates decreased from $460 \mathrm{mg} \mathrm{m}^{-2} \mathrm{~s}^{-1}$ in the lower part of the mudflat during the first hour to 60

$320 \mathrm{mg} \mathrm{m}^{-2} \mathrm{~s}^{-1}$ in the middle part of the mudflat during the next $40 \mathrm{~min}$ and increased again to 300

$321 \mathrm{mg} \mathrm{m}^{-2} \mathrm{~s}^{-1}$ during the next $30 \mathrm{~min}$. In contrast, in the Eulerian survey, PIM concentration

322 decreased, with values remaining within the $80 \%$ confidence interval of predicted dilution by

323 offshore waters (Fig. 4).

3.3 Changes in the concentration of autotrophic microorganisms during the Eulerian and Lagrangian surveys

The dynamics of the various taxa of autotrophic microorganisms counted during the

328 Lagrangian and Eulerian surveys was compared to initial concentration and predicted changes

329 by mixing with offshore waters, respectively. At the beginning of both surveys, two third of 330 diatoms were benthic species. This proportion increased during the Lagrangian survey to 331 nearly $80 \%$. In the Eulerian survey, this proportion decreased to less than $20 \%$, reflecting the 332 differential effect of resuspension and mixing with offshore waters on water column 333 microorganism dynamics. Although changes in benthic diatom concentration during the 334 Lagrangian survey suggested alternate phases of gain in the lower and upper parts of the 335 mudflat, where erosion was the greatest, and loss in the middle regions of the mudflat, none of 336 these changes were beyond the $80 \%$ confidence interval of the initial concentrations 337 determined at the beginning of the survey (Fig. 5a). However, the decrease in benthic diatom 338 concentration was not statistically significant. In contrast, a predicted significant increase in 
pelagic diatoms was observed during the Eulerian survey. During the Lagrangian survey,

340 changes in pelagic diatoms concentration were again not statistically significant given the

341 large variability observed at the beginning of survey (Fig. 5b).

Smallest autotrophs were mainly comprised of ANF (0.6 to $1 \times 10^{4}$ cells $\mathrm{mL}^{-1}$ ) in both

343 surveys, whereas picophytoeukaryotes and Synechococcus sp. (e.g. cyanobacteria) displayed

344 very low concentrations (Fig. 5b-d). During the Lagrangian survey, ANF concentration nearly

345 doubled during the first $1 \mathrm{~h} 15$ min, departing from $80 \%$ confidence interval around value

346 when surveys started, and then decreased during the next hour (Fig. 5b). During the Eulerian survey, ANF concentration displayed opposite dynamics at the surface and at the bottom. In any case, by the end of the survey, values at the surface and at the bottom overpassed the $80 \%$ confidence interval around values predicted from dilution with offshore waters.

Picoeukaryotes concentration steadily decreased during the Lagrangian survey.

However, this trend was not statistically significant given the large variation coefficient at the beginning of survey (Fig. 5c). During the Eulerian survey, picoeukaryote concentration displayed opposite dynamics at the surface and at the bottom, increasing at the surface and decreasing at the bottom (Fig. 5c). However, values were never outside the large 80\% confidence interval around values predicted from mixing with offshore waters. during both surveys (Fig. 5d), with values lower than the $80 \%$ confidence interval of 358 predicted mixing by offshore waters.

\subsection{Changes in the concentration of heterotrophic microorganisms during the}

\section{Eulerian and Lagrangian surveys}

During the Lagrangian survey, free virus concentration steadily decreased from $1.2 \mathrm{x}$ $10^{7}$ particles $\mathrm{mL}^{-1}$ to $7 \times 10^{6}$ particles $\mathrm{mL}^{-1}$ (Fig. 6a). However, this decrease was not

364 statistically significant. During the Eulerian survey, free virus concentration at the surface 

interval).

steadily decreased within the $80 \%$ confidence interval of predicted dilution by offshore waters. Conversely, at the bottom, free virus concentration significantly increased during the first $1 \mathrm{~h} 15 \mathrm{~min}$, reaching a value of $1.8 \times 10^{7}$ viruses $\mathrm{mL}^{-1}$. This value was out of the $80 \%$ confidence interval around values predicted from dilution by offshore waters and even out of the $80 \%$ confidence interval around value when survey started. However, free viruse concentration at the bottom decreased during the next $1 \mathrm{~h} 30 \mathrm{~min}$, reaching a value of $4 \times 10^{6}$ viruses $\mathrm{mL}^{-1}$, which was within the $80 \%$ confidence interval around values predicted from dilution by offshore waters.

Free bacteria dynamics were similar to free virus dynamics during both surveys (Fig. 6b). For attached bacteria concentration, no significant change was observed during the Lagrangian survey (6-8 x 10 cells $\mathrm{mL}^{-1}$ ), while concentration decreased during the Eulerian survey by one order of magnitude, which was still within the $80 \%$ confidence interval of predicted dilution with offshore waters (Fig. 6c).

The dynamics of HNF was similar to the ANF dynamics in the both surveys. During the Lagrangian survey, HNF concentration increased steadily over the first 2 h10 min to almost twice the concentration measured at the start of the survey $\left(3 \times 10^{3}\right.$ cells $\mathrm{mL}^{-1}$ ), but then decreased during the last 30 min (Fig. 6d). During the Eulerian survey, HNF concentration displayed opposite dynamics at the bottom and at the surface, but both values remained within the $80 \%$ confidence interval around surveys initial value and the large $80 \%$ confidence interval around values predicted from mixing with offshore waters $\left(1.3 \times 10^{3}\right.$ cells $\left.L^{-1}\right)$.

During the Lagrangian survey, ciliate concentration doubled along the transect to values greater than the $80 \%$ confidence interval estimated when the survey began (Fig. 6e). During the Eulerian survey, ciliate concentration decreased at the bottom and at the surface more than expected from dilution with offshore waters at the bottom (i.e. lower than the $80 \%$ confidence 
In summary, the water column only became significantly enriched with nanoflagellates

392 (autotrophs and heterotrophs) and ciliates during the Lagrangian survey over the mudflat,

393 where resuspension occurred. In contrast, mixing (typically leading to dilution) with offshore

394 waters was observed at the Eulerian site, except for free viruses and free bacteria at the

395 bottom (gain), ANF (gain) and Synechococcus and ciliates (loss). No significant change was

396 detected in autotroph biomass in any of the surveys (Fig. 7a) or in heterotroph biomass during

397 the Lagrangian survey (Fig. 7b). In contrast, heterotroph biomass was decreased by 50\% at

398 the end of the Eulerian survey as expected from dilution with less heterotrophic offshore

399 waters (Fig. 7b). Regardless, heterotroph biomass remained greater than autotroph biomass

400 throughout both surveys.

401

402

\section{Discussion}

In the present study, we aimed at testing in situ whether and how the pelagic system

404 structure was modified during the rising tide by physical transfer of autotrophic and 405 heterotrophic microorganisms. Physical transfer included mixing with offshore waters and 406 sediment erosion and was evidenced by temporal changes in particulate inorganic matter 407 concentration.

\subsection{Decrease of resuspended microorganisms by grazing predators}

Over the mudflat, significant sediment erosion occurred under wave action, but at

410 different rates across the intertidal area. These changes were reflected by subsequent changes

411 in erodibility across the mudflat as bed friction velocity was kept constant during the

412 Lagrangian survey. A very low erosion rate in the middle region of the Brouage mudflat with

413 large bed friction velocities was indicative of low erodibility of the consolidated sediment,

414 possibly due to desiccation during tidal emersion (Anderson and Howell 1984; Paterson et al.

415 1990). On July 24, water content in the upper layer of mud fell from 55 to $46 \%$ during the $4 \mathrm{~h}$

416 low tide. Such periods of desiccation occurred on many days throughout the particularly dry, 
417 windy and hot month of July 2008 (Dupuy et al., personal communication). Variability in

418 erosion rates across the mudflat may also be attributed to changes in bioturbation intensity

419 (Widdows et al. 1998). Specifically, more active bioturbators in the Brouage mudflat, such as

420 Scorbicularia plana (Orvain 2005), are generally more abundant in the upper mudflat

421 (Sauriau et al. 1989; Bocher et al. 2007; Orvain et al. 2007). Moreover, erodibility increase

422 due to bioturbation activity should also be enhanced by low tide duration: the upper in the

423 mudflat, the longer the low tide and hence, the higher the bioturbation pressure. Surprisingly,

424 the input of taxon that are generally abundant in the sediment, such as diatoms, bacteria and

425 nanoflagellates (Paterson et al. 2009), was not observed during sediment erosion. Differences

426 in resuspension thresholds for benthic microorganisms may have been due to cell size,

427 specific gravity, behaviour, or association with particles (Shimeta et al. 2002). However, bed

428 friction velocities reaching an average of $3.2 \mathrm{~cm} \mathrm{~s}^{-1}$ due to waves prevented sedimentation of particles with settling velocities less than $4 \mathrm{~cm} \mathrm{~s}^{-1}$ (i.e. particles with diameters smaller than $320 \mu \mathrm{m})$ (Fredsöe and Deigaard 1992). Thus, considering the much lower density of organic matter compared to sedimentary matter and suspension thresholds determined by Shimeta et al. (2002), suspension thresholds were reached for all microorganisms included in the present study. Moreover, wave vertical velocities were undoubtedly greater than the swimming speed of any of these microorganisms ( $<1 \mathrm{~mm} \mathrm{~s}^{-1}$, Bauerfeind et al. 1986), precluding any migration process. In addition, all microorganisms counted in the present study were found at high densities in the Brouage muddy sediment before the rising tide, except for ciliates. As such, a significant increase in microorganism concentrations was expected to occur along with erosion of the muddy bed. Conversely, a stagnation or a decrease in the concentration of any 439 microorganism during the Lagrangian survey therefore most likely indicated consumption by 440 grazers.

Guarini et al. (2008) developed a model that simulates the dynamics of microalgal 442 biomass in semi-enclosed littoral ecosystems and suggested that resuspension of the MPB 
443 occurs at the beginning of the rising tide, even in the absence of simultaneous sediment

444 erosion. Such recurrent MPB resuspension is consistent with the high proportion of benthic

445 diatom species observed at the beginning of both surveys in the present study. Meanwhile,

446 enrichment in benthic diatoms species was not significant in our survey. However, benthic

447 diatom concentration simultaneously increased with mud erosion in the lower and upper part

448 of the mudflat. Of the smaller autotrophs, only ANF significantly increased in the lower part

449 of the mudflat, where sediment erosion was greatest, during the first hour of the Lagrangian

450 survey. This significant increase in ANF concentration in the water column suggests that ANF

451 concentrations in eroded sediment during the survey was at least $10^{6}$ cell $\mathrm{mL}^{-1}$, which is a

452 hundred times greater than previously reported average values in the first top cm of the BMO

453 sediment $\left(10^{4}\right.$ cell $\mathrm{mL}^{-1}$, C. Dupuy personal communication). Yet, ANF most probably

454 accumulated at the very surface of sediment in a layer of 1-2 cells thickness, just like diatoms

455 does, to photosynthesize (Guarini et al., 2000). These findings support routine measurement

456 of the detailed vertical distribution of microorganisms for estimation of erosion fluxes.

457 Synechococcus concentrations remained low, and picophytoeukaryote concentration

458 decreased during the same period. We therefore suggest that the erosion flux of benthic

459 diatoms and ANF, largely present at the mud surface, was immediately overwhelmed by a

460 grazing flux due to heterotrophic protists (HNF, ciliates), micrometazoan and mesometazoans

461 planktonic organisms (Sherr et al. 1986; Leakey et al. 1992; Calbet et al. 2008) or benthic

462 suspension feeders (Hughes 1969; Carlson et al. 1984).

$463 \quad$ Free virus concentration decreased during the Lagrangian survey, while it was expected

464 to increase with resuspension as these microorganisms are also largely present in mud $\left(10^{10}\right.$

465 cell $\mathrm{mL}^{-1}$ sediment; Hewson et al. 2001, and the present study). Again, this suggests that virus

466 resuspension flux during the rising tide due to waves was compensated by a loss process.

467 However, adsorption of free viruses onto clay particles may also occur in addition to or as an

468 alternative to grazing (Malits and Weinbauer 2009). Reversible sorption and hydrophobic 
469 effects are linked to the ionic strength of the given environment, most notably to the

470 concentration of cations like $\mathrm{Na}^{+}$, which may change between bed sediment and water (Gerba

471 1984). Finally, water agitation has been recently shown to enhance viral sorption to clay

472 (Syngouna and Chrysikopoulos 2010). Therefore, together with wave agitation, availability of

473 sorption sites on the clayed mud of the BMO (Helton et al. 2006), salt water may favour virus

474 adsorption onto sedimentary particles. Similar to viruses, electrostatic properties, $\mathrm{pH}$,

475 temperature, and salinity are thought to govern the sorption of bacterial cells onto clay

476 minerals (Jiang et al. 2007). As such, bacteria adsorption onto resuspended sedimentary

477 particles should not be excluded during the Lagrangian survey. Free bacteria concentration

478 remained constant while an increase was expected as these organisms are abundant in the mud

479 (5.10 cell $\mathrm{mL}^{-1}$, Garet 1996 and $10^{9}$ cell $\mathrm{mL}^{-1}$ in the present study) and were undoubtfully

480 resuspended. However, no significant enrichment in attached bacteria was observed during

481 the Lagrangian survey despite that a thousand-fold enrichment was expected from the large

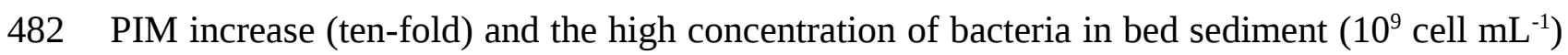

483 compared to water $\left(10^{6}\right.$ cell $\left.\mathrm{mL}^{-1}\right)$. As free virus concentration did not strongly increased,

484 significant enhancement of virally mediated bacterial mortality was unlikely. Thus, attached

485 and free bacteria were most likely heavily grazed immediately after resuspension during the

486 Lagrangian survey.

487 Significant HNF concentration increase during the Lagrangian survey is consistent with

488 expected resuspension of benthic HNF given the bed friction velocities (due to waves) that

489 largely exceeded thresholds for HNF resuspension (Shimeta et al. 2002; 0.25-0.80 $\mathrm{cm} \mathrm{s}^{-1}$ ). In

490 contrast, HNF production (secondary production) could not explain concentration doubling,

491 given nanoplankton growth rate ranging from $7 \mathrm{~h}$ (Dupuy et al, 2007) to $20 \mathrm{~h}$ (Calbet et al.

492 2008; Liu et al. 2009). Thus, doubling of HNF concentration in the water column suggest that

493 HNF concentration in eroded sediment during the survey was roughly $10^{5}$ cell $\mathrm{mL}^{-1}$, which is

494 a hundred times greater than previously reported average values found in the first top cm of 
495 the BMO sediment $\left(10^{3}\right.$ cell $\mathrm{mL}^{-1}$, C. Dupuy personal communication). This result suggests

496 that HNF accumulated at the very surface of sediment during the present study and pinpoints

497 again the importance of accounting for vertical distribution of microorganisms when

498 estimating erosion fluxes. Similar zonation of nanoflagellates at the surface of sediment

499 compared to deeper layers have been previously reported during summer periods in the North

500 Sea (Hondeveld et al. 1994) and also in the BMO in July 2008 (Dupuy et al., submitted). In

501 any case, after 2 h, the decrease in HNF concentration during the Lagrangian survey indicated

502 grazing on HNF by ciliates or micrometazoan and mesometazoan planktonic organisms

503 (Sherr et al. 1986; Hartmann et al. 1993; Calbet et al. 2008) also buffered resuspension flux.

504 In contrast, a significant increase in ciliate concentration during the Lagrangian survey

505 could not be attributed to benthic transfer that accompanies mud erosion. Although some

506 ciliate genera can be found in sediment, such as scuticociliates (Uronema sp.), ciliate

507 concentration is generally very low in mud sediments (Giere 1993), with concentrations lower

508 than 20 cell $\mathrm{mL}^{-1}$ in the BMO surficial sediment (C. Dupuy, personal communication).

509 Simulated erosion of sediment cores taken in the BMO during the same period as the present

510 study confirmed ciliates erosion was unsignificant (C. Dupuy, personal communication).

511 Besides, ciliates taxa found in the present study were Order Oligotrichida (Strombidium spp.)

512 and Order Tintinnida (Tintinnopsis spp.), which are generally part of the suprabenthos due to

513 behavioural adaptations leading to depth zonation above the sediment-water interface after

514 vertical migration when vertical flow motion is small. Compared to other groups of

515 microorganisms analysed in the present study, ciliates are relatively more motile organisms

516 (velocities up to $0.5 \mathrm{~mm} \mathrm{~s}^{-1}$ ) that can control their position in the water column at low

517 turbulence levels (Jonsson 1989). Ciliate concentration increase during the Lagrangian survey

518 may be attributed to redistribution by waves vertical stirring of ciliates accumulated at a

519 particular depth during slack tide. 
Mixing (dilution or enrichment) with offshore waters was expected during the Eulerian

523 survey, where water depth varied. It should be noted that the $80 \%$ confidence interval around 524 prediction from mixing with offshore waters reduces when offshore waters are less

525 concentrated than inner basin waters (heterotrophic microorganisms) while it is reversed when

526 offshore are more concentrated than inner basin waters (autotrophic microorganisms). Thus,

527 detecting deviation from dilution prediction should be more accuratethan detecting deviation

528 from import prediction.

The PIM concentration evolved as predicted by dilution during the Eulerian survey,

530 indicating that no significant erosion or sedimentation occurred. Thus, settling velocity of

531 suspended particles should be comparable to mean wave bed friction velocities, ranging from

5321.4 to $0.5 \mathrm{~cm} \mathrm{~s}^{-1}$, while bed sediment erosion threshold should be larger than $1.4 \mathrm{~cm} \mathrm{~s}^{-1}$. In

533 contrast, during the Lagrangian survey, a strong increase in PIM concentration indicated that

534 bed friction velocities were high enough to erode the mud. Bed friction velocity due to the 535 tidal current $\left(1.3 \mathrm{~cm} \mathrm{~s}^{-1}\right)$ was lower than the largest bed friction velocity observed during the 536 Eulerian survey which did not cause significant erosion. Thus, mud erosion during the 537 Lagrangian survey was more likely driven by bed friction velocities due to waves (average 538 velocity of $3.2 \mathrm{~cm} \mathrm{~s}^{-1}$ and $4.5 \mathrm{~cm} \mathrm{~s}^{-1}$ maximum) as suggested by Bassoullet et al. (2000). 539 However, the current study only indicates that the erosion threshold for the fine-grained mud 540 sediment of the Brouage mudflat (median grain size was 10 to $12 \mu \mathrm{m}$ ) lies between $1.4 \mathrm{~cm} \mathrm{~s}^{-1}$

541 (largest value during Eulerian survey during which erosion was not observed) and $4.5 \mathrm{~cm} \mathrm{~s}^{-1}$ 542 (largest value during Lagrangian survey during which erosion was obsrved) in terms of bed 543 friction velocity.

During the Eulerian survey, no significant change in diatom concentration was detected 546 reflecting similar order of magnitude of concentration in the inner basin and in the north of 
547 the basin. However, a total community change occurred with replacement of benthic diatoms

548 by pelagic diatoms in proportion of water depth change during the rising tide. No significant

549 primary production of diatoms was expected given the short duration of the Eulerian survey

550 compared to the generation time for microphytoplankton (1 division $\mathrm{d}^{-1}$, Calbet and Landry

5512004 to 2 divisions $d^{-1}$, Dupuy et al. 2007) and water turbidity (Struski and Bacher 2006;

552 Bouman et al. 2010). Thus, mixing was the most likely dominant process.

Significantly lower than expected concentrations (based on mixing with offshore

554

555

556

557

558

559

560

561

562

563

564

565

566

567

568

569

570

571

\subsection{Strengths and limitations of the sampling strategy}


573 resuspension and separating physical processes from biotic processes using PIM as a

574 reference lead to the conclusion that grazing pressure must be intense during rising tide.

575 However, temporal changes in concentrations that follow the dilution curve in an Eulerian

576 survey or remain constant in a Lagrangian survey simply mean that loss and gain processes

577 balance each other out. In addition, conclusive demonstration of loss or gain processes

578 requires that temporal changes in surveys are larger than uncertainties on initial conditions. In

579 the present study, uncertainties in PIM, diatoms, picoeukaryotes and attached bacteria

580 concentrations at the beginning of surveys reached $100 \%$, which prevented the detection of

581 any significant decrease. Yet, significant increases could be detected when values more than

582 doubled, as seen for PIM. These large uncertainties have different origins. For PIM,

583 uncertainties were mainly due to large differences between the Lagrangian and Eulerian

584 samples taken when surveys started and advocate for increasing sampling effort and

585 localization precision in the intertidal area where large horizontal spatial gradients may exist.

586 For diatoms, attached bacteria and picoeukaryotes, large uncertainties also came from large

587 difference between the Eulerian samples and points out the low precision on concentration

588 determination for some microorganisms. Reducing these uncertainties requires increased

589 sample volume and superior enumeration efforts.

\section{5. Conclusions}

During a rising tide, expected water column enrichment of benthic microorganisms

593 (small to large autotrophs and heterotrophs) from sediment resuspension was largely

594 overwhelmed by loss processes, except for nanoflagellates (ANF and HNF). The dominant

595 loss process was likely grazing. However, adsorption onto clayed particles may have also

596 masked enrichment for free viruses and bacteria . A combination of resuspension and

597 grazing/adsorption processes led to non-significant changes in both heterotroph and autotroph 
total biomass during the rising tide in the nearshore area. In the meanwhile, offshore waters

599 imported autotrophic organisms, mainly Synechococcus, while heterotrophic microorganisms

600 were diluted. However, autotrophic organisms import was significantly grazed. As a result,

601 combination of offshore waters import and grazing led to stability of autotrophs biomass in

602 the deeper areas of the BMO, while heterotrophs biomass was reduced by 50\%. Lastly, when

603 resuspension occurred over a tidal flat during a rising tide, the water column evolved to a less

604 heterotrophic structure over the mudflat in the deepest part of the semi-enclosed bay

605 compared to nearshore. Thus, the present study suggests that this differential evolution mainly

606 reflects dilution with low concentrated offshore waters, as grazing pressure erased any

607 microorganisms inputs accompanying physical transfers due to bed erosion or offshore waters

608 mixing.

609

610 Acknowledgments

611 The work was supported by the French ANR (Agence Nationale pour la Recherche)

612 through the VASIREMI project “Trophic significance of microbial biofilms in tidal flats”

613 (grant no. ANR-06-BLAN-0393-01). We are grateful to Martine Bréret, Camille Fontaine,

614 Françoise Mornet and the personnel at both RV Tidalou and Estran for their technical support.

615 We thank Pierre Richard for the Lagrangian buoys. We are also grateful to Carolyn Engel-

616 Gautier and Proof-reading-service.com Ltd for English corrections.

617

618

619

620

621

622

623 


\section{References}

625

626 Alongi, D. M. 1991. Flagellates of benthic communities: characteristics and methods of study, p. 57-75. In D. J. Patterson [ed.], The Biology of Free-living Heterotrophic Flagellates. Clarendon Press, Oxford.

Aminot, A., and M. Chaussepied. 1983. Manuel des analyses chimiques en milieu marin. CNEXO, Brest.

631

632

633

Anderson, F. E., and B. A. Howell. 1984. Dewatering of an unvegetated muddy tidal flat during exposure - dessication or drainage? Estuaries 7: 225-232.

Bassoulet, P., P. Le Hir, D. Gouleau, and S. Robert. 2000. Sediment transport over an intertidal mudflat: field investigations and estimation of fluxes within the 'Baie de Marennes-Oleron (France). Cont. Shelf Res. 20: 1635-1653.

Bauerfeind, E., Elbrächter, M., Steiner, R. and J. Thronden. 1986. Application of Laser Doppler Spectroscopy (LDS) in determining swimming velocities of motile phytoplankton. Mar Biol 93: 323-327.

Blanchard, G.F, and V. Cariou-Le Gall. 1994. Photosynthetic characteristics of microphytobenthos in Marennes-Oleron Bay, France : Preliminary results. J. Exp. Mar. Biol. Ecol. 182: 1-14.

Blanchard, G.F., J. M. Guarini, P. Richard, and P. Gros. 1997. Seasonal effect on the relationship between the photosynthetic capacity of intertidal microphytobenthos and short-term temperature changes. J. Phycol. 33: 723-728.

Blanchot, J., and M. Rodier. 1996. Picophytoplankton abundance and biomass in the western tropical Pacific Ocean during the 1992 El Nino year: results from flow cytometry. Deep Sea Res Part I: Oceanogr. Res. Papers 43: 877-895.

Bocher, P., T. Piersma, A. Dekinga, C. Kraan, M. G. Yates, T. Guyot, E. O. Folmer, and G. Radenac. 2007. Site- and species-specific distribution patterns of mollusks at five 
intertidal soft-sediment areas in northwest Europe during a single winter. Mar. Biol. 151:577-594.

652 Bouman, H. A. , T. Nakane, K. Oka, K. Nakata, K. Kurita, S. Sathyendranath, and T. Platt. 2010. Environmental controls on phytoplankton production in coastal ecosystems: A case study from Tokyo Bay. Est. Coast. Shelf. Sci. 87: 63-72.

Calbet, A., and M. R. Landry. 2004. Phytoplankton growth, microzooplankton grazing, and carbon cycling in marine systems. Limnol. Oceanogr. 49:51-57.

Calbet, A., I. Trepat, R. Almeda, V. Saló, E. Saiz, J. I. Movilla, M. Alcaraz, L. Yebra, and R. Simó. 2008. Impact of micro- and nanograzers on phytoplankton assessed by standard and size-fractionated dilution grazing experiments. Aquat. Microb. Ecol. 50: 145-156.

Cammen, L.M. 1991. Annual bacterial production in relation to benthic microalgal production and sediment oxygen uptake in an intertidal sandflat and an intertidal mudflat. Mar. Ecol. Prog. Ser.71: 13-25.

Caron, D. A. 1983. Technique for enumeration of heterotrophic and phototrophic nanoplankton, using epifluorescence microscopy, and comparison with other procedures. Appl. Environ. Microbiol. 46: 491-498.

666 Carlson, D.Townsend, D. W., Hilyard, A. L., Eaton J. F. 1984. Effect of an Intertidal Mudflat 667 on Plankton of the Overlying Water column. Can. J. Fish. Aquat. Sci., 41, 1523-1528.

Danovaro, R., C. Corinadelsi, M. Filippini, U. R. Fisher, M. O. Gessner, S. Jacquet, M. 669 Magagnini, and B. Velimirov. 2008. Viriobenthos in freshwater and marine sediments: a review. Fresh. Biol. 53: 1186-1213.

671 Dupuy, C., S. Le Gall, H. J. Hartmann, and M. Bréret. 1999. Retention of ciliates and flagellates by the oyster Crassostrea gigas in French Atlantic coastal ponds: protists as a trophic link between bacterioplankton and benthic suspension-feeders. Mar. Ecol. Prog. Ser. 177: 165-175. 
Dupuy, C., A. Pastoureaud, M. Ryckaert, P. G. Sauriau, and H. Montanié. 2000. Impact of the oyster Crassostrea gigas on the microbial community in Atlantic coastal ponds near La Rochelle. Aquat. Microb. Ecol. 22: 227-242.

Dupuy, C., M. Ryckaert, S. Le Gall, and H. J. Hartmann. 2007. Seasonal variations of planktonic communities in Atlantic Coastal pond: importance of nanoflagellates. Microb. Ecol. 53: 537-548.

Epstein, S. S. 1997. Microbial food webs in marine sediments. I. Trophic interactions and grazing rates in two tidal flat communities. Microb. Ecol. 34:188-198.

Fenchel, T. 1969. The ecology of marine microbenthos. IV. Structure and function of the benthic ecosystem, its chemical and physical factors and the microfauna communities with special reference to the ciliated protozoa. Ophelia 5:1-182.

Fredsoe, J., and R. Deigaard. 1992. Mechanics of coastal sediment transport. 369 p. In World Scientific [ed.], Advanced Series on Ocean Engineering 3.

French, J.R., H. Burningham, and T. Benson. 2008. Tidal and Meteorological Forcing of Suspended Sediment Flux in a Muddy Mesotidal Estuary. Estuaries Coasts 31 : 843859.

Fournier, J., Dupuy, C., Bouvy, B., Courrodon-Real, M., Charpy, L., Pouvreau, S., Le Moullac, G., Le Pennec, M., Cochard, J.C. 2012 Pearl oysters Pinctada margaritifera grazing on natural plankton in Ahe atoll lagoon (Tuamotu archipelago, French Polynesia). Marine Pollution Bulletin 65 : 490-499

Garet, M. J. 1996. Transformation bactérienne de la matière organique dans les sédiments côtiers. Relation entre les métabolismes respiratoires et les activités exoprotéolytiques bactériennes, phD Microbiologie : Univ. Bordeaux 2.

Garstecki, T., S. A. Wickham, and H. Arndt. 2002. Effects of experimental sediment resuspension on a coastal planktonic microbial food web. Est. Coast. Shelf. Sci. 55: 751-762. 
Gasol, J. M. 1993. Benthic flagellates and ciliates in fine freshwater sediments: calibration of a live counting procedure and estimation of their abundances. Microb. Ecol. 25:247262.

Gerba, C. P. 1984. Applied and theoretical aspects of virus adsorption to surfaces, 30: 133168. In Advances in Applied microbiology [ed.], Academic press, Inc.

Giere, O. 1993. Meiobenthology. The microscopic fauna in aquatic sediments, 328 pp. Springer-Verlag, Berlin.

Grémare, A., Amouroux, J.M., Cauwet, G., Charles, F., Courties, C., deBovée, F., Dinet, A., Devenon, J.L., Durrieu de Madron, X., Ferré, B., Fraunié, P., Joux, F., Lantoine, F., Lebaron, P., Naudin, J.J., Palanques, A., Pujo-Pay, M., Zudaire, L. 2003. The effects of a strong winter storm on physical and biological variables at a shelf site in the Mediterranean. Oceanologica Acta, 26(4), 407-419.

Guarini, J. M., Blanchard, G.F., Gros, Ph., Gouleau, D., Bacher, C. 2000. Dynamic model of the short-term variability of microphytobenthic biomass on temperate intertidal mudflats. Mar. Ecol. Prog. Ser. 195: 291-303.

Guarini, J. M., N. Sari, and C. Moritz. 2008. Modelling the dynamics of the microalgal biomass in semi-enclosed shallow-water ecosystems. Ecol. Modeling 211: 267-278.

Guizien, K., F. Charles, D. Hurther, and H. Michallet. 2010. Spatial redistribution of Ditrupa arietina (soft bottom Mediterranean epifauna) during a moderate swell event: evidence and implications for biotic quality indices. Cont. Shelf Res. 30: 239-251.

Guizien, K., and A. Temperville. 1999. Frottement de fond sous une houle irrégulière. C. R. Acad. Sci. Paris, t. 327, Série Iib: 1375-1378.

Haas, L.W. 1982. Improved epifluorescence microscopy for observing planktonic microorganisms. Ann. Inst. Oceanogr. 58: 261-266. 
724 Hartmann, H. J., H. Taleb, L. Aleya, and N. Lair. 1993. Predation on ciliates by the suspension-feeding calanoid copepod Acanthodiaptornus denticornis. Can. J. Fish. Aquat. Sci. Paris. 50:1382-1393.

Hervouet, J. M., and L. Van Haren. 1994. TELEMAC-2D Principle Note (Electricité de France, Technical Report HE- 43/94/051/B).

Hervouet, J. M. 2007. Hydrodynamics of Free Surface Flows: Modelling With the Finite Element Method, Wiley-Blackwell, 360 pp.

Hewson, I., J. M. O’Neil, C. Heil, G. Bratbak, and D. Dennison. 2001. Effects of concentrated viral communities on photosynthesis and community composition of co-occuring benthic microalgae and phytoplankton. Aquat. Microb. Ecol. 25: 1-10.

Herlory, O., J. M. Guarini, P. Richard, and J. F. Blanchard. 2004. Microstructure of 735 microphytobenthic biofilm and its spatio-temporal dynamics in an intertidal mudflat

Hondeveld B.J.M., Nieuwland G., van Duyl F.C., Bak R.P.M. 1994. Temporal and spatial variations in heterotrophic nanoflagellate abundance in North Sea sediment. Mar. Ecol. Prog. Ser. 109: 235-243.

Hughes, R.N. 1969. A study of feeding in Scrobicularia plana. J. Mar. Biol. Ass. U. K. 49: 805-823.

Jiang, D., Q. Huang, P. Cai, X. Rong, and W. Chen. 2007. Adsorption of Pseudomonas putida on clay minerals and iron oxide. Colloids and surfacesB : Biointerfaces 54: 217221. experimental analysis of swimming behaviour. Mar. Ecol. Prog. Ser. 52: 39-53. on sediment bacteria. Mar. Ecol. Prog. Ser. 49:163-169. 
749 Koroleff, F., 1969. Direct determination of ammonia as indophenol blue. International 750 Council for the Exploration of the Sea, 1969/C:9, Hydrol Commun, pp 19-22.

751 Labry, C., A. Herbland, and D. Delmas. 2002. The role of phosphorus on planktonic 752 production of the Gironde plume waters in the Bay of Biscay. J. of Plankton Res. 24: 97-117.

754 Leakey, R. J. G., P. H. Burlull, and M. A. Sleigh. 1992. Planktonic ciliates in Southampton 755 Water: abundance, biomass, production, and role of pelagic carbon flow. Mar. Biol. 14: 67-83.

Liu, H., K. Suzuki, J. Nishioka, R. Sohrin, and T. Nakatsuka. 2009. Phytoplankton growth and microzooplankton grazing in the Sea of Okhotsk during late summer of 2006. Deep-Sea Res. I. 56: 561-570.

Lucas, C.H., J. Widdows, M. D. Brinsley, P. N. Salkeld , and P. M. J. Herman. 2000. Benthicpelagic exchange of microalgae at a tidal flat. 1. Pigment analysis. Mar. Ecol. Prog. Ser. 196: 59-73.

Malits, A., and M. G. Weinbauer. 2009. Effect of turbulence and viruses on prokaryotic cell size, production and diversity. Aquat. Microb. Ecol. 54: 243-254.

Marie, D., F. Partensky, N. Simon, L. Guillou, and D. Vaulot. 2000. Flow cytometry analysis

Marquis, E., N. Niquil, D. Delmas, H. J. Hartmann, D. Bonnet, F. Carlotti, A. Herbland, C.

Mehta, J.A., E. J. Hayter, W. R. Parker, R. B. Krone, and A. M. Teeter. 1989. Cohesive sediment transport. I. Process description. J. Hydraulic Eng. 115:1076-1093. 
774 Nezan, E., 1996. Surveillance du Phytoplankton marin : manuel illustré adapté à la formation 775 des analystes. (IFREMER, Eds.). Brest.

776 Nicolle, A., and M. Karpytchev. 2007. Evidence for spatially variable friction from tidal amplification and asymmetry in the Pertuis Breton (France). Cont. Shelf Res. 27: 2346-

779 2356.

Noble, R.T., and J. A. Fuhrman. 1998. Use of SYBR Green I for rapid epifluorescence counts of marine viruses and bacteria. Aquat. Microb. Ecol. 14: 113-118.

Orvain, F. 2005. A model of sediment transport under the influence of bioturbation activities: generalisation to a key-species Scrobicularia plana. Mar. Ecol. Progr. Ser. 286: 43-56.

Orvain F., P. G. Sauriau, A. Sygut, L. Joassard, and P. Le Hir. 2004. Roles of Hydrobia ulvae bioturbation and the physiological stage of microphytobenthic mats in resuspended sediment and pigment fluxes. Mar. Ecol. Prog. Ser. 278: 205-223.

Ory, P., H. J. Hartmann, F. Jude, C. Dupuy, Y. Del Amo, P. Catala, F. Mornet, V. Huet, B. Juan, D. Vincent, B. Sautour, and H. Montanié. 2010. Pelagic food web patterns: do they modulate virus and nanoflagellate effects on picoplankton during the phytoplankton spring bloom? Environ. Microbiol., 12 : 2755-2772

Ory, P., Palesse, S., Delmas ,D. and Montanié H., 2011 In situ structuring of virioplancton through bacterial exoenzymatic activity ; interaction with phytoplnkton. Aquatic microbial ecology, 64: 233-252.

Paterson, D.M., R. M. Crawford, and C. Little. 1990. Subaerial exposure and changes in the stability of intertidal estuarine sediments. Est. Coast. Shelf. Sci. 30:541-556.

Paterson, D. M., R. Aspden, and K. S. Black. 2009. Intertidal flats: Ecosystem functioning of soft sediments systems. In: Perillo GME, Wolanski E, Cahoon DR, Brinson MM [ed.], Coastal Wetlands: An Integrated Ecosystem Approach. Elsevier. 
Pelegri, S. P., J. R. Dolan, and F. Rassoulzadegan. 1999. Use of high temperature catalytic oxidation (HTCO) to measure carbon content of microorganisms. Aquat. Microb. Ecol. 16: $273-280$.

Pusceddu, A., C. Fiordelmondo, and R. Danovaro. 2005. Effects on the Benthic Microbial Loop in Experimental Microcosms. Microb. Ecol. 50: 602-613.

Ricard, M., 1987. Atlas du phytoplancton marin, vol. 2. (CNRS, Eds.). Paris.

Schmidt, J. L., J. W. Deming, P. A. Jumars, and R. G. Keil. 1998. Constancy of bacterial abundance in surficial marine sediments. Limnol. Oceanogr. 43: 976-982.

Seymour, J. R., L. Seuront, and J. G. Mitchell. 2007. Microscale gradients of planktonic microbial communities above the sediment surface in a mangrove estuary. Est. Coast. Shelf. Sci. 73: 651-666

Sherr, E., B. F. Sherr, and G. A. Paffenhofer. 1986. Phagotrophic protozoa as food for metazoans: a "missing" trophic link in marine pelagic food webs? Mar. Microb. Food Webs 1:61-80.

Sherr, E. B., D. A. Caron, and B. F. Sherr. 1994. Staining of heterotrophic protists for visualisation via epifluorescence microscopy. In: Kemp, PF, Sherr, BF, Sherr, EB, Cole, JJ [ed.], 213-227.Handbook of Methods in Aquatic Microbial Ecology. Lewis Publishers, Boca Raton, FL.

Shimeta, J., and J. Sisson. 1999. Taxon-specific tidal resuspension of protists into the subtidal benthic boundary layer of a coastal embayment. Mar. Ecol. Prog. Ser. 177: 51-62.

Shimeta, J, C. L. Amos, S. E. Beaulieu, and O. M. Ashiru. 2002. Sequential resuspension of protists by accelerating tidal flow: Implications for community structure in the benthic boundary layer. Limnol. Oceanogr. 47: 1152-1164. 
821 Shimeta, J., C. L. Amos, S. E. Beaulieu, and S. L. Katz. 2003. Resuspension of benthic protists at subtidal coastal sites with differing sediment composition. Mar. Ecol. Prog. Ser. 259: 103-115.

824 Sournia, A., 1986. Atlas du phytoplancton marin, vol. 1. (CNRS, Eds.). Paris.

825 Struski, C., and C. Bacher. 2006. Preliminary estimate of primary production by phytoplankton in Marennes-Oleron Bay, France. Est. Coast. Shelf. Sci. 66: 323-334.

827 Syngouna, V.I. and Chrysikopoulos, C.V. 2010. Interaction between viruses and clays in stat828 ic and dynamic bacth system. Environ Sci Technol 44: 4539-4544

829 Van Duyl, F.C., and A. J. Kop. 1994. Bacterial production in North Sea sediments: clues to 830 seasonal and spatial variations. Mar. Biol. 235: 323-327.

831 Widdows, J., M. D. Brinsley, and M. Elliott. 1998. Use of in situ flume to quantify particle flux. 139:85-97, In: Black K.S., Paterson D.M., Cramp A. [ed.], Sedimentary processes in the Intertidal Zone. Geol. Soc. London, Special publication.

834 Wu, Q. L., Y. Chen, K. Xu, Z. Liu, and M. W. Hahn. 2007. Intra-habitat heterogeneity of mi835 crobial food web structure under the regime of eutrophication and sediment resuspension in the large subtropical shallow Lake Taihu, China. Hydrobiologia 581: 241-254. 
Figure 1: Map of the Marennes-Oléron Bay in Europe. The grey area indicates land and the contour labeled 0 delimites the largest extent of the intertidal area (lowest sea level during the highest tidal coefficient). Open circles indicate the successive locations of the Lagrangian survey stations, the open square indicates the Eulerian survey location and the filled triangle indicates the ADV location. Trajectories simulated with the Telemac model are displayed: thin lines figure trajectories reaching the Eulerian survey location at 17:20 h (solid) and 18:40 $\mathrm{h}$ (dashed) and the thick line figures trajectory leaving the Eulerian survey location at 16:00 h.

Figure 2: Expected temporal changes in concentrations during a Lagrangian survey (black line) and during a Eulerian survey (gray line) of the water column.

Figure 3: (a) Wind speed at La Rochelle Aérodrome and significant wave height $\left(\mathrm{H}_{\mathrm{S}}\right)$ on the intertidal flat during high tide (light gray) on 24 July, 2008. (b) Measured bed friction velocities associated with the tidal current (open triangles) and computed bed friction velocities associated with waves in a constant $40 \mathrm{~cm}$ water depth during the Lagrangian survey (filled circles for the maximum, open circles for the average) and for water depth increasing from 1.1 to $3.1 \mathrm{~m}$ during the Eulerian survey (filled squares for the maximum, open squares for the average).

Figure 4: Temporal changes in concentration of particulate inorganic matter (PIM) in the middle of the water column during the Lagrangian survey (white bar) and during the Eulerian survey (square) at the surface (gray) and at the bottom (white) of the water column. The black vertical bar represents the average concentration in the middle of the water column in the lower part of the mudflat when surveys started with its $80 \%$ confidence interval. Lines display the $80 \%$ confidence interval of concentrations calculated assuming only mixing with 
incoming offshore waters when tide rose during the Eulerian survey (see formula in the Methods section).

Figure 5: Temporal changes in the abundances of autotrophic organisms: benthic diatoms (a), pelagic diatoms (b), autotrophic nanoflagellates (ANF, c), Picophytoeukaryots (d) and Synechococcus (e) in the middle of the water column during the Lagrangian survey (white bar) and during the Eulerian survey (square) at the surface (gray) and at the bottom (white) of the water column. The black vertical bar represents the average concentration in the middle of the water column in the lower part of the mudflat when surveys started with its $80 \%$ confidence interval. Lines display the $80 \%$ confidence interval of concentrations calculated assuming only mixing with incoming offshore waters when tide rose during the Eulerian survey (see formula in the Methods section).

Figure 6: Temporal changes in the abundances of heterotrophic organisms: free viruses (a), free bacteria (b), attached bacteria (c), heterotrophic nanoflagellates (HNF, d) and ciliates (e) in the middle of the water column during the Lagrangian survey (white bar) and during the Eulerian survey (square) at the surface (gray) and at the bottom (white) of the water column. The black vertical bar represents the average concentration in the middle of the water column in the lower part of the mudflat when surveys started with its $80 \%$ confidence interval. Lines display the $80 \%$ confidence interval of concentrations calculated assuming only mixing with incoming offshore waters when tide rose during the Eulerian survey (see formula in the Methods section).

Figure 7: Temporal trends in the autotrophs (a) and heterotrophs (b) biomass in the middle of the water column during the Lagrangian survey (white bar) and during the Eulerian survey (square) at the surface (gray) and at the bottom (white) of the water column. The black 
vertical bar represents the average concentration in the middle of the water column in the lower part of the mudflat when surveys started with its $80 \%$ confidence interval. 
Table 1: Concentrations of parameters at the north station on July 12 and 29, 2008, used as offshore value $\mathrm{C}_{\mathrm{ext}}$ in equation (1).

\begin{tabular}{|l|l|}
\hline & July 12 / July 29 \\
\hline PIM & 18.2 / 6.67 mg L \\
\hline Pelagic diatoms & $112.7 / 52.8$ cell $\mathrm{mL}^{-1}$ \\
\hline Benthic diatoms & $17.3 / 4.2$ cell $\mathrm{mL}^{-1}$ \\
\hline ANF & $1.8 / 1.010^{3}$ cell $\mathrm{mL}^{-1}$ \\
\hline Picoeukaryots & $5.5 / 2.8810^{3}$ cell $\mathrm{mL}^{-1}$ \\
\hline Synechococcus sp. & $1.44 / 2.2510^{4}$ cell $\mathrm{mL}^{-1}$ \\
\hline Free virus & $3.8 / 2.3410^{6}$ cell $\mathrm{mL}^{-1}$ \\
\hline Free bacteria & $2.65 / 2.4810^{6}$ cell $\mathrm{mL}^{-1}$ \\
\hline Attached bacteria & $5.3 / 7.510^{3}$ cell $\mathrm{mL}^{-1}$ \\
\hline HNF & $1.5 / 0.610^{3}$ cell $\mathrm{mL}^{-1}$ \\
\hline Ciliates & $3.66 / 4.58$ cell $\mathrm{mL}^{-1}$ \\
\hline
\end{tabular}


Table 2: Conversion factors and their corresponding literature reference used to convert abundance to biomass of carbon for each type of plankton organism.

\begin{tabular}{|l|l|l|}
\hline Cells or organism & Conversion factor (pg C/cell) & Reference \\
\hline Bacteria & 0.016 & Labry et al. (2002) \\
\hline Synechococcus & 0.104 & Blanchot and Rodier (1996) \\
\hline Picoeukaryotes & 0.104 & Blanchot and Rodier (1996) \\
\hline Nanoflagellates & 3.14 & Pelegri et al. (1999) \\
\hline Ciliates & 3.14 & Pelegri et al. (1999) \\
\hline Diatoms & 225 & Fournier et al. (2012) \\
\hline
\end{tabular}




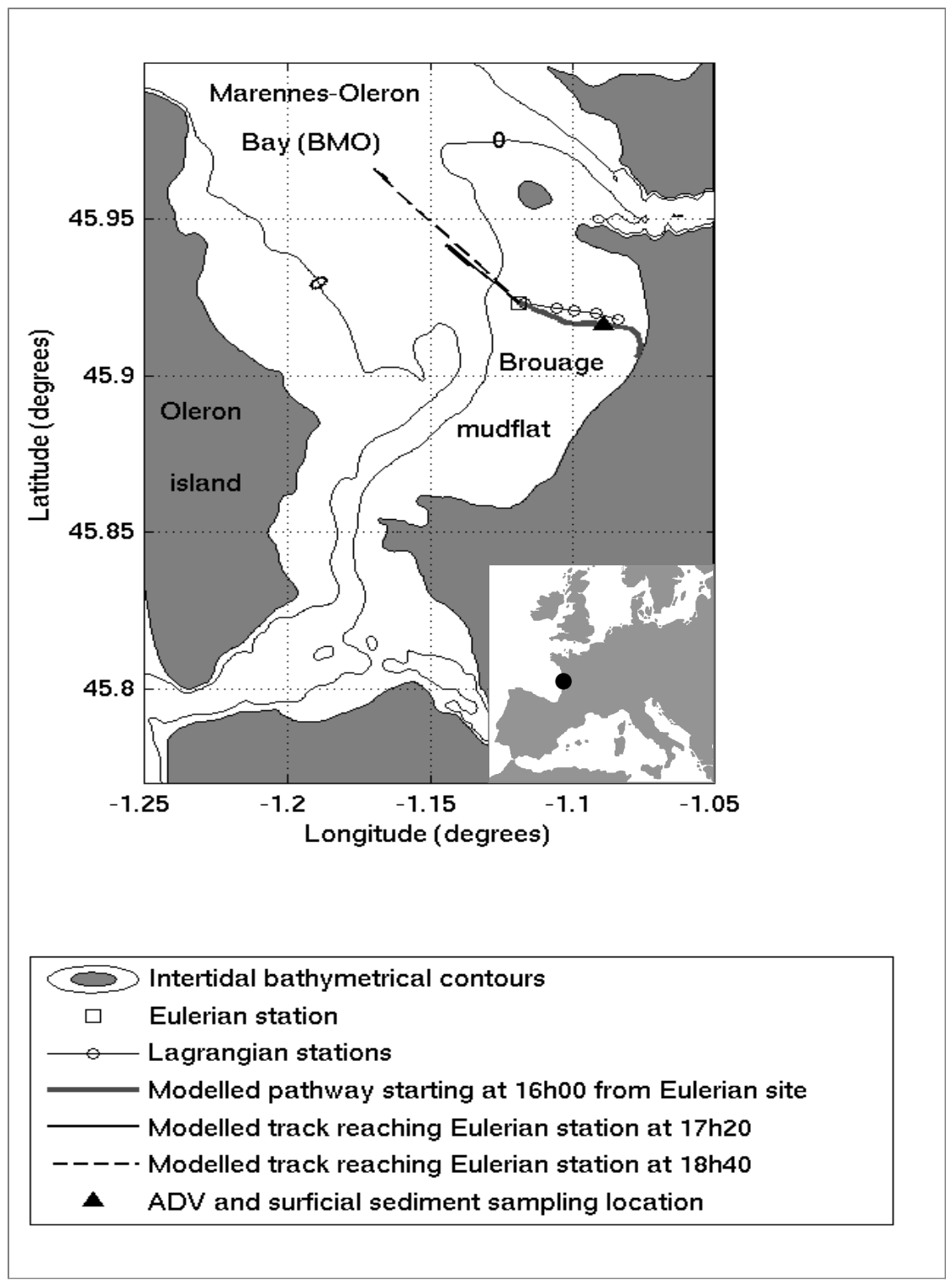

Figure 1 


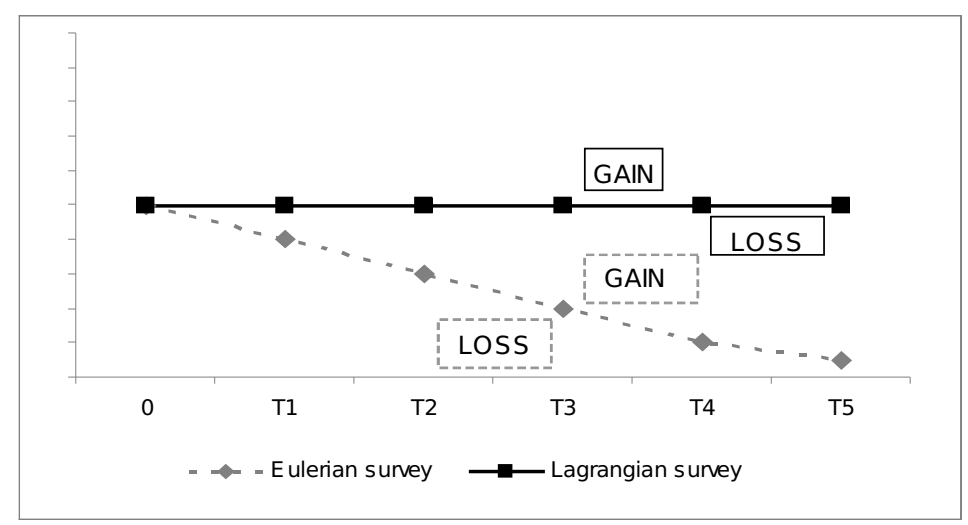

Figure 2 


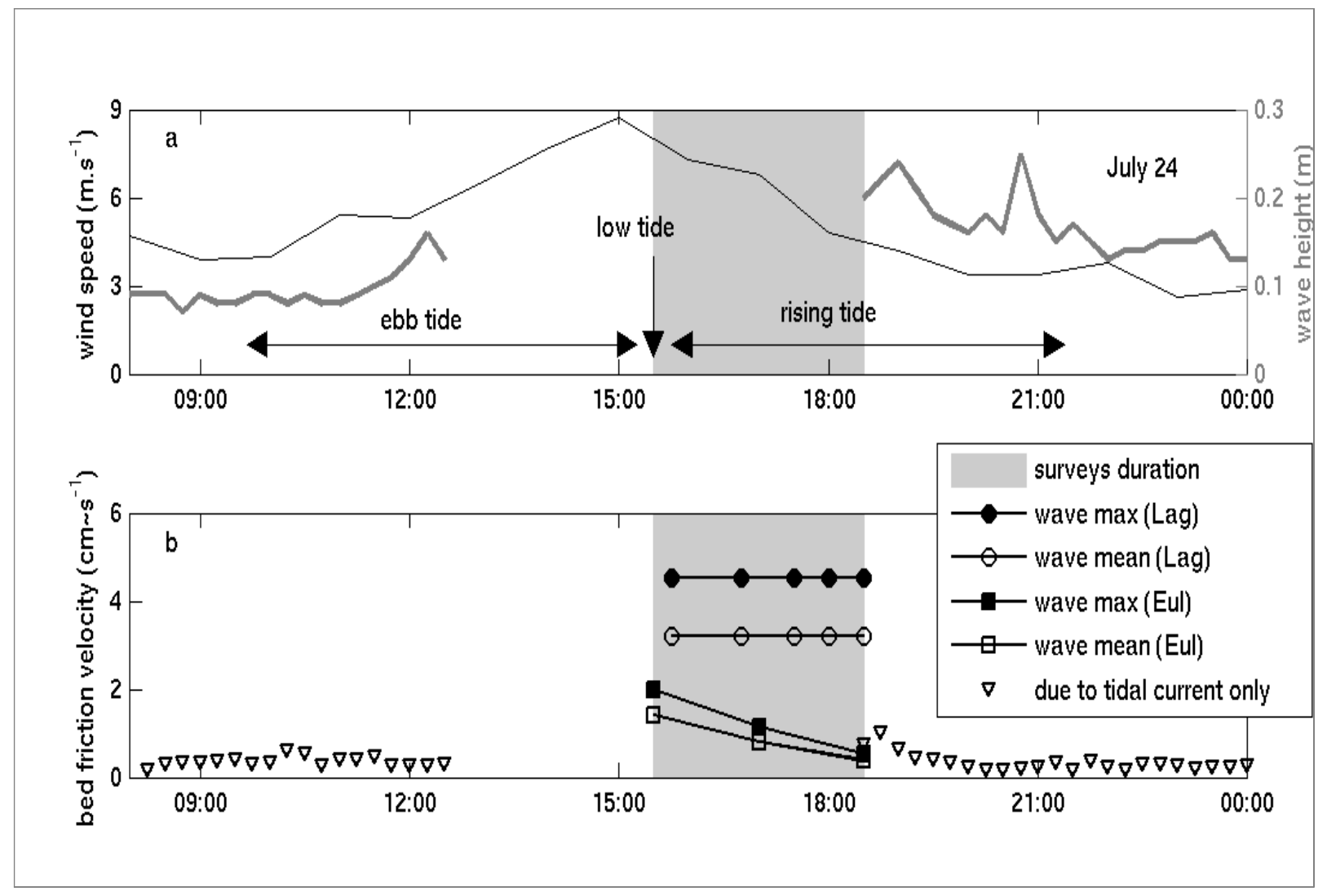

Figure 3 


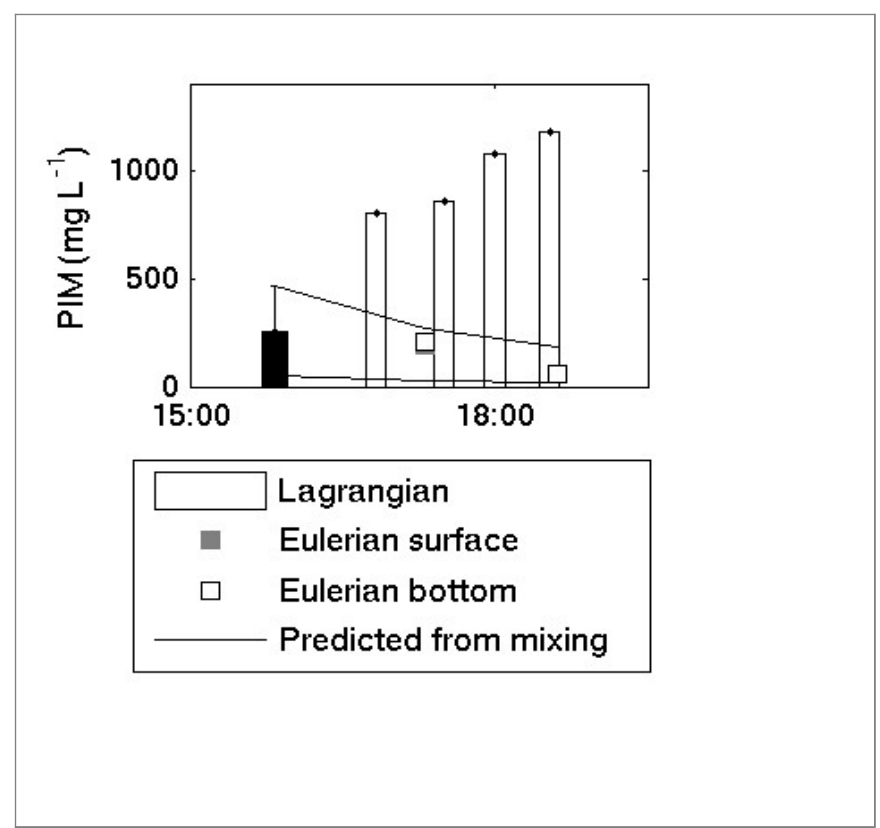

Figure 4 

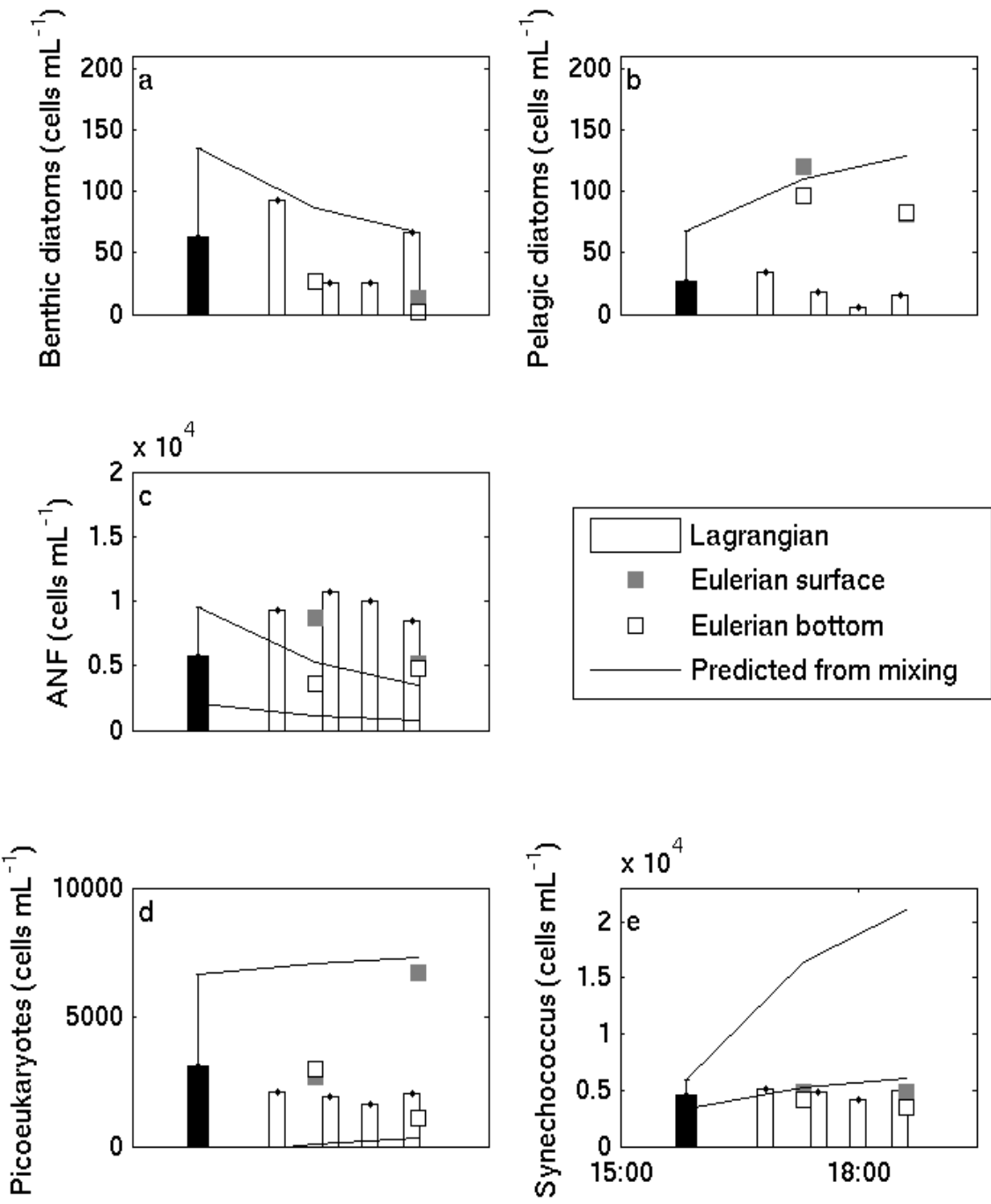

Figure 5 

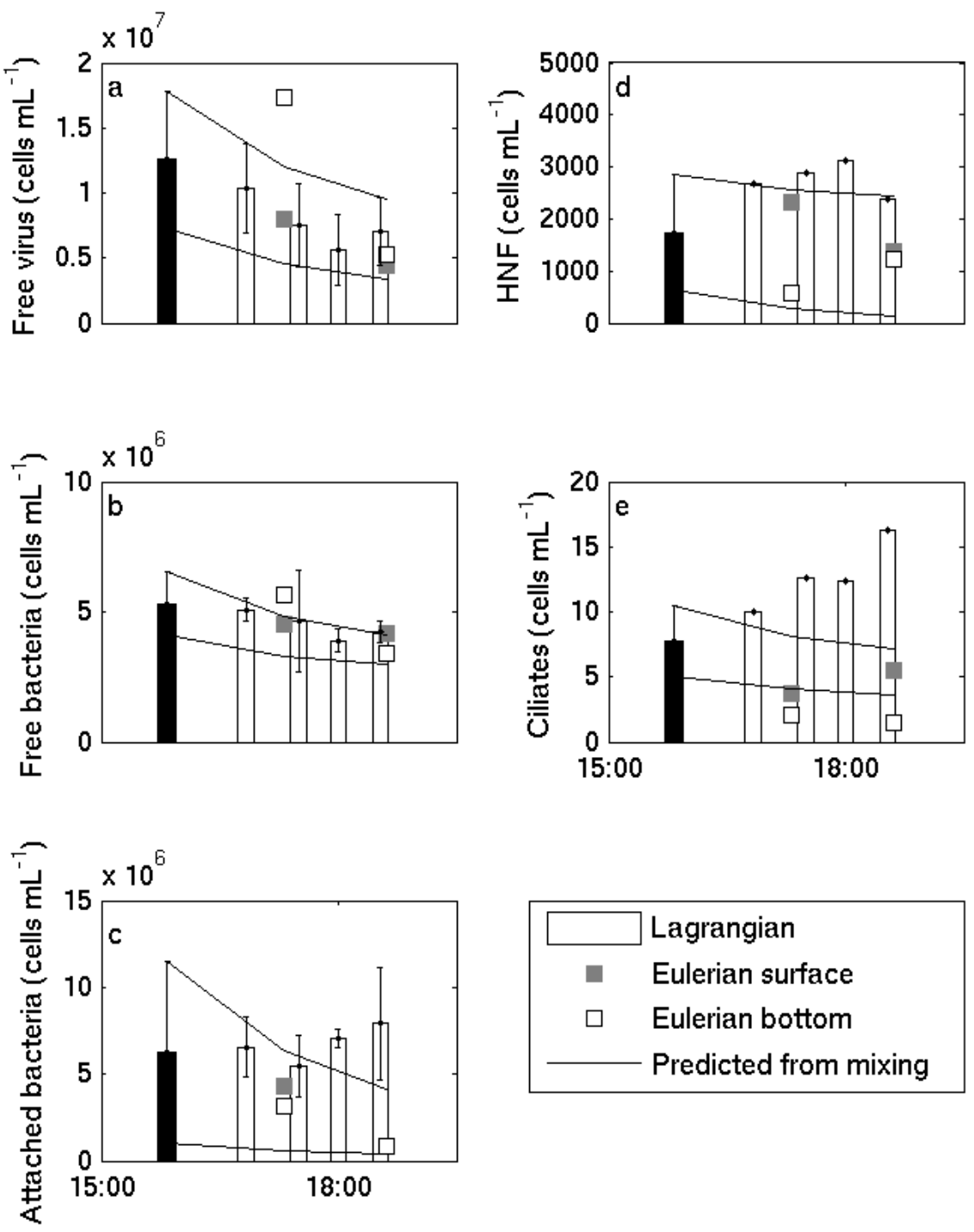

Figure 6 

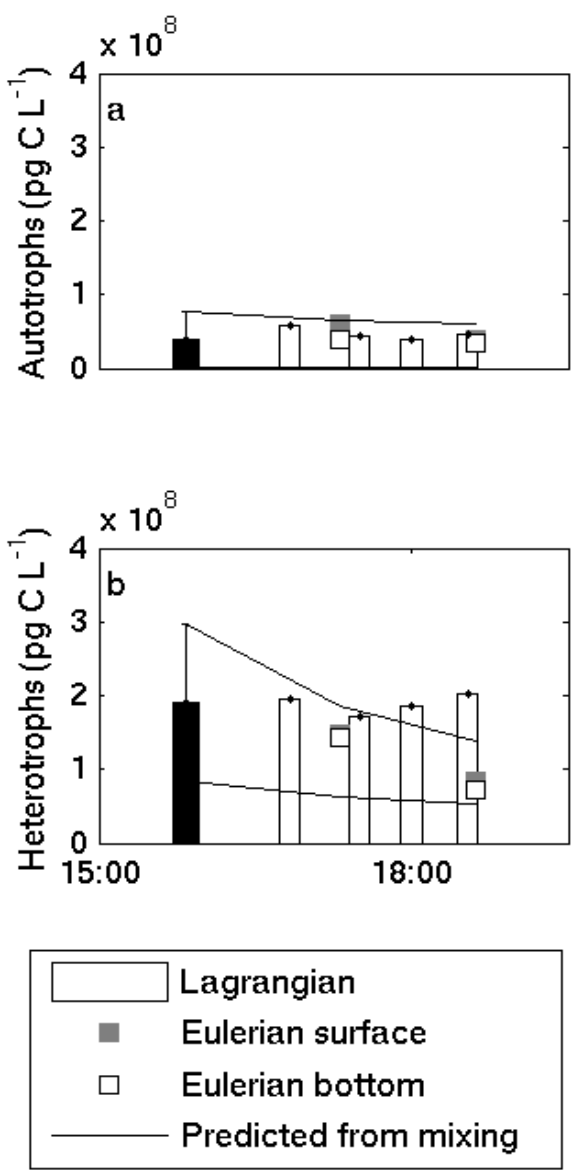

Figure 7 